\title{
Hematologic Evaluation of Painting Hall Workers in an Automobile Manufacturing Company
}

\author{
Bahram Harati, ${ }^{1}$ Seyed Jamaleddin Shahtaheri, ${ }^{2,}{ }^{*}$ Ali Karimi, ${ }^{3}$ Kamal Azam, ${ }^{4}$ Ali Harati, ${ }^{5}$ Alireza \\ Ahmadi, ${ }^{6}$ and Maryam Afzali $\operatorname{Rad}^{7}$ \\ ${ }^{1}$ M.Sc., Department of Occupational Health Engineering, School of Public Health, Tehran University of Medical Sciences, Tehran, Iran \\ ${ }^{2}$ Professor of Occupational Health Engineering, School of Public Health, Institute for Environmental Research, Tehran University of Medical Sciences, Tehran, Iran \\ ${ }^{3}$ Assistant Professor of Occupational Health Engineering, School of Public Health, Tehran University of Medical Sciences, Tehran, Iran \\ ${ }^{4}$ Assistant Professor of Biostatistics, Department of Epidemiology and Biostatistics, School of Public Health, Tehran University of Medical Sciences, Tehran, Iran \\ ${ }^{5}$ B.Sc. Student, Department of Occupational Health Engineering, School of Public Health, Islamic Azad University, Boroujerd Branch, Boroujerd, Iran \\ ${ }^{6}$ B.Sc., Department of Occupational Health Engineering, School of Public Health, Shahid Beheshti University of Medical Sciences, Tehran, Iran \\ ${ }^{7}$ B.Sc., Department of Occupational Health Engineering, School of Public Health, Tehran University of Medical Sciences, Tehran, Iran \\ "Corresponding author: Seyed Jamaleddin Shahtaheri, Professor of Occupational Health Engineering, School of Public Health, Institute for Environmental Research, Tehran \\ University of Medical Sciences, Tehran, Iran. Tel: +98-2142933133, E-mail: shahtaheri@tums.ac.ir
}

Received 2017 July 03; Revised 2017 August 29; Accepted 2017 September 06.

\begin{abstract}
Background: Exposure to benzene causes several adverse effects, including decreased number of erythrocytes, leucocytes, and red blood cells, and results in aplastic anemia. The aim of this study was to investigate hematological changes due to benzene exposure in painting workers.

Methods: This study was conducted on benzene-exposed and nonexposed workers in Tehran, Iran. The study sample included 40 painters exposed to different levels of benzene and 40 unexposed controls in an automobile manufacturing company. Sampling was carried out with an active pump sampler, using the NIOSH method 1501. Varian C-3800 gas chromatography-flame ionization detector (GC-FID) was used for the analysis of 40 benzene samples. Blood samples from 80 workers were collected from both the case and control groups. Hematological indices were analyzed for red blood cell, white blood cell, hematocrit, hemoglobin, platelet, and white cell differential count.

Results: The average amount of benzene in painting workers was $0.775 \pm 0.12 \mathrm{ppm}$. Benzene was not detected in the breathing zone of the control group. Long-term occupational exposure to benzene was lower than $1 \mathrm{ppm}$. Some blood indices, including the mean corpuscular hemoglobin concentration (MCHC) and eosinophil count, showed significant differences in comparison with the control group $(\mathrm{P}<0.05)$. However, no significant differences were observed in the hematocrit, hemoglobin, mean corpuscular volume (MCV), and $\mathrm{MCH}$ of painters, compared to the control group $(\mathrm{P}>0.05)$. Moreover, the platelet count was normal in workers with exposure to benzene.

Conclusions: The painters showed evidence of relative exposure to benzene at a concentration below 1 ppm, causing changes in blood cells. The results of this study demonstrated that eosinophils are more sensitive than lymphocytes or neutrophils.

Keywords: Benzene, Hematologic, Painter
\end{abstract}

\section{Background}

Over the past years, Iran has shown significant growth in major industries, such as petrochemical and oil industries (1). Almost 4 million people around the world are exposed to different chemical substances (2). Volatile organic compounds (VOCs) are among important chemical substances in oil industry and painting processes. VOCs are present in the workplace and urban areas at different concentrations (3).

Benzene is the simplest VOC and an excellent organic solvent (4). Its emission, reported as parts per billion ( $\mathrm{ppb}$ ) or parts per million (ppm), in different processes is a serious hazard to the environment $(5,6)$. Benzene is present in gasoline and is emitted from fire. It is a component of crude oil and gasoline, emitted from various oil processes (4). It is also present in cigarette smoke. Therefore, this compound, found in cigarette smoke and other products, may cause concerns for public health (7-9).

Benzene has been shown to cause cancer and produce group-1 human carcinogens. Accordingly, it has been classified by the international agency for research on cancer (IRAC) (1982). There is an agreement that benzene can affect the hematopoietic system (10). It seems that all humans may be exposed to benzene. Therefore, exposure to benzene can cause toxic effects on red blood cell (RBC) metabolization.

The relationship between benzene concentration in 
the breathing zone of workers and benzene metabolites has adverse effects on healthy workers (5). Exposure to various concentrations of benzene causes several adverse effects, including hematological system and central nervous system malfunctions (11). The hematopoietic toxicity of benzene has been reported in studies by Selling (12) and Weiskotten $(4,13,14)$. Long-term exposure to benzene can lead to leukemia and may cause lymphoma in humans (15). High concentrations of benzene cause adverse effects on the hematopoietic system (hematotoxicity) (11); however, low hematotoxicity is undetermined in long exposures.

Exposure to various concentrations of benzene, ranging from $1 \mathrm{ppm}$ to hundreds of ppm, results in the reduction of white blood cells (WBCs), RBCs, and platelet count. Reduction in complete blood cell (CBC) count to levels below the normal limit is termed as pancytopenia, leading to aplastic anemia (16). Some authors have proposed hemoglobin $(17,18)$, mean corpuscular volume (MCV) (19, 20), absolute lymphocyte count (21-23), and CBC count (2426) as appropriate tests for the detection of toxic effects.

In a previous study, Hemberg reported cytopenia in workers exposed to benzene (27). The comparison of CBC count in a study by Colliins showed no significant differences in hemoglobin, RBC, and MCV in benzene-exposed workers. On the other hand, Colliins showed a scarcely significant increase in MCV, associated with benzene in the workplace (28). Moreover, exposure to benzene can lead to carcinogenicity in humans (29). The aim of this study was to investigate the hematological indices of benzene exposure to determine the correlation of exposure to benzene $(<1 \mathrm{ppm})$ with immunological parameters and hematological changes in painting workers.

\section{Methods}

This cross sectional control-group study was conducted in Tehran, Iran. The subjects included 40 painters exposed to different levels of benzene and 40 unexposed controls at an automobile manufacturing company. Air and blood samples were collected from the workplace. The inclusion criteria for the group of painting workers were as follows: 1, at least 1 year of experience in the painting hall; and 2, lack of chronic diseases, such as anemia, hypertension, liver diseases, and kidney diseases. In total, 45 workers were in the painting hall, 5 of whom were removed after checking due to hereditary anemia. The control group was selected from the administrative personnel. Moreover, 20 samples were enrolled in the control group ( 2 samples from each person).

\subsection{Sampling and Analysis of Benzene}

Sampling and analysis of inhaled benzene were carried out using NIOSH method 1501. A total of 40 samples were collected from 20 painters ( 2 samples from each painter) during 120 hours (3 hours per sample). The samples were collected at different working hours due to different levels of air pollution and work shifts. The air samples were aspirated in the sampling tubes, containing activated coconut shell charcoal.

After collection of benzene from the breathing zone, the compounds were extracted with carbon disulfide $\left(\mathrm{CS}_{2}\right.$; $2 \mathrm{~mL}$ ). Varian c-3800 gas chromatography-flame ionization detector (GC-FID) was used for the analysis of 40 benzene samples. The concentration of benzene in the breathing zone ranged from 0.54 to $0.86 \mathrm{ppm}$. The period of exposure to benzene ranged from 1 to 20 years. For determining the total benzene level in the breathing zone of painting workers, the amount of the sample in the front and back of the activated charcoal absorber was analyzed. Finally, for measuring the analyte concentration in the air volume, the following equation was used:

$\mathrm{C}=\left(\mathrm{W}_{\mathrm{f}}+\mathrm{W}_{\mathrm{b}}-\mathrm{B}_{\mathrm{f}}-\mathrm{B}_{\mathrm{b}}\right) / \mathrm{V}$

where $W_{f}$ refers to the analyte in the sample front, $W_{b}$ is the analyte found in the sample back, $B_{f}$ is the average media blank front, and $\mathrm{B}_{\mathrm{b}}$ is the average media blank back. Also, $V$ refers to the air volume sample (L), and $C$ denotes the concentration of pollutant $\left(\mathrm{mg} / \mathrm{m}^{3}\right)$.

For calculating ppm at vapor pressure of $760 \mathrm{mmHg}$, the following equation was applied:

$\mathrm{ppm}=\mathrm{mg} / \mathrm{m}^{3} \times 24.45 / \mathrm{M}$

where $\mathrm{M}$ represents the molecular weight (benzene, 78.11).

Moreover, for calculating the time-weight average (TWA), the following equation was used:

TWA $=\mathrm{C}_{1} \mathrm{~T}_{1}+\mathrm{C}_{2} \mathrm{~T}_{2} / 8$

where $C$ is the concentration of pollutant (ppm), and $T$ is the duration of sampling (hours).

\subsection{Hematological Measurements}

Blood samples were collected from 80 workers from both the case and control groups. The samples were collected from painting workers and controls in the morning and stored at $4^{\circ} \mathrm{C}$. Analysis of blood samples was performed in the laboratory within 3 hours after collection in the workplace. The hematological indices were analyzed for RBC, WBC, hematocrit, hemoglobin, platelet, and white cell differential count.

\subsection{Statistical Analysis}

Data were analyzed using SPSS version 22. One-way ANOVA and multiple regression analysis were performed 
to compare the mean pollutant concentration and hematological indices and to determine the relationship between parameters.

\section{Results}

\subsection{History of Workers and Controls}

A total of 40 male painters (age range, 25 - 54 years; mean, $34.22 \pm 6.85$ ), who were exposed to benzene for 2 to 16 years (mean, $6.9 \pm 4.13$ ) and worked $8-10 \mathrm{~h} /$ day, were compared with 40 unexposed men (age range, 36 52 years; mean, $44.5 \pm 4.27$ ) in the automobile manufacturing factories of Tehran, Iran. The control group was not exposed to any solvents. Statistical analysis showed significant differences in the age, work experience, and education of benzene-exposed and control groups $(\mathrm{P}<0.001)$. The characteristics of benzene-exposed and control groups are summarized in Table 1.

\subsection{Personal air Benzene Exposure}

In total, 40 samples were collected from the factories ( 6 samples in 1 day and 40 samples in 1 month). The concentration of benzene in the breathing zone of painters ranged from 0.54 to $0.83 \mathrm{ppm}$ in 1 day with a TWA of 0.69 $\pm 0.14 \mathrm{ppm}$. The average 1 -month benzene exposure in the painting halls ranged from 0.54 to $0.86 \mathrm{ppm}$, with a TWA of $0.775 \pm 0.12 \mathrm{ppm}$ (Table 2).

Comparison of benzene concentration with the recommended level showed that in the breathing zone, the benzene level was significantly higher than the recommended threshold limit value (TLV)-TWA by the American Conference of Governmental Industrial Hygienists (ACGIH) (TWA, $0.5 \mathrm{ppm}$ ) in pollutant-exposed workers. The results demonstrated a significant difference in benzene concentration in the breathing zone of workers with permitted level of $0.5 \mathrm{ppm}(\mathrm{P}=0.003)$. However, benzene was not detected in the breathing zone of the controls.

\subsection{Hematological Changes}

Blood samples were collected from 80 workers (painting workers and controls), and $\mathrm{CBC}$ count was analyzed. The mean eosinophil count was lower in the benzeneexposed group, compared to the controls. There was a significant difference $(\mathrm{P}<0.001)$ in the eosinophil count between the groups.

The mean corpuscular hemoglobin concentration (MCHC) significantly increased in the benzene-exposed group, compared to the control group $(\mathrm{P}<0.01)$. Comparison of hematological parameters showed no significant differences between the groups in terms of hemoglobin, hematocrit, $\mathrm{MCV}, \mathrm{MCH}, \mathrm{RBC}$, platelet count, erythrocyte sedimentation rate (ESR), red cell distribution width (RDW), WBC, neutrophil, lymphocyte, and monocyte count $(\mathrm{P}>0.05)$. The results presented in Table 3 indicate the differences in hematological indices between the unexposed and exposed subjects to benzene.

In this study, the mean hematocrit, MCV, ESR, RDW, WBC, neutrophil, eosinophil, and monocyte level in smoking painters were higher than their nonsmoking counterparts, although the statistical analysis showed no significant differences between smoking and nonsmoking painters $(P>0.05)$. The mean hematocrit, MCV, ESR, WBC, neutrophil, and eosinophil levels in smoking subjects (smoking painting workers and smoking controls) were higher than their nonsmoking counterparts in the 2 groups (nonsmoking painting workers and nonsmoking controls); however, the statistical analysis showed no significant differences between the groups ( $\mathrm{P}>0.05)$. The information of smoking and nonsmoking workers is summarized in Table 4.

Multiple regression analysis of hematological parameters in terms of age, work experience, smoking, and body mass index (BMI) between benzene-exposed painting workers is summarized in Table 5 . The results showed a significant difference in monocyte count and work experience $(P=0.02)$. However, the statistical analysis showed no significant differences between hematological parameters and age, smoking, and BMI ( $\mathrm{P}>0.05)$.

\section{Discussion}

Benzene exposure is still reported in both occupational and environmental settings, although its occurrence has reduced over the past decades. Today, occupational exposure is normally below the regulatory standard of $1 \mathrm{ppm}$ and is often below $0.1 \mathrm{ppm}$. However, identifying higher levels of exposure (> $10 \mathrm{ppm}$ ) in small and unregulated environments is an important step in bridging the information gap (9).

Exposure to high concentrations of benzene may decrease the blood cell count $(30,31)$. Long-term exposure to different levels of benzene in the workplace may be associated with adverse health effects, such as reduced total WBC (32). According to the finding of this study, benzene concentration (0.775 ppm) among painters was higher than the standard recommended by ACGIH. In this regard, a large study indicated that hematotoxicity might occur in workers exposed to benzene concentrations below $1 \mathrm{ppm}$ (26). According to the finding of this study, painting workers exposed to benzene showed significant hematological changes. The mean eosinophil count significantly decreased in workers exposed to benzene, compared to the control group. Conversely, the mean MCHC significantly 
Table 1. Demographic Information of Benzene-Exposed and Control Groups (N, 80 $)^{\mathrm{a}}$

\begin{tabular}{|c|c|c|c|}
\hline Variables & Benzene Exposed $(\mathbf{N}, \mathbf{4 0})$ & Control Group (N, 40) & P Value \\
\hline Age, $y$ & $34.22 \pm 6.85$ & $44.55 \pm 4.27$ & $<0.001$ \\
\hline Work experience, $y$ & $6.9 \pm 4.13$ & $16.77 \pm 3.37$ & $<0.001$ \\
\hline Education & & & $<0.001$ \\
\hline Below college & $23(57.5)$ & $6(15)$ & \\
\hline College or higher & $17(42.5)$ & $34(85)$ & \\
\hline Body mass index, $\mathrm{kg} / \mathrm{m}^{2}$ & & & 0.051 \\
\hline$<25$ & $23(57.5)$ & $14(35)$ & \\
\hline $25-30$ & $11(27.6)$ & $16(40)$ & \\
\hline$>30$ & $6(15)$ & $10(25)$ & \\
\hline Smoking & & & 0.63 \\
\hline Yes & $15(37.5)$ & $13(32.5)$ & \\
\hline No & $25(62.5)$ & $27(67.5)$ & \\
\hline
\end{tabular}

${ }^{\mathrm{a}}$ Values are expressed as mean $\pm \mathrm{SD}$ or No. (\%).

Table 2. Exposure to Benzene Among Painting Workers in an Automobile Manufacturing Factory in Tehran, Iran

\begin{tabular}{|c|c|c|c|c|c|}
\hline \multirow[t]{2}{*}{ Concentrations } & \multirow[t]{2}{*}{ Number of Samples } & \multicolumn{2}{|c|}{ Benzene } & \multirow[t]{2}{*}{ TLV-TWA (ACGIH), ppm } & \multirow[t]{2}{*}{ PValue } \\
\hline & & TWA & Range & & \\
\hline Level in 1 day, ppm & 6 & $0.69 \pm 0.14$ & $0.54-0.83$ & 0.5 & 0.04 \\
\hline Average in 4 weeks, ppm & 40 & $0.775 \pm 0.12$ & $0.54-0.86$ & 0.5 & 0.003 \\
\hline
\end{tabular}

Table 3. Hematological Parameters in the Benzene-Exposed and Control Groups (N, 40)

\begin{tabular}{|c|c|c|c|}
\hline Variables & Benzene-Exposed Group & Control Group & P Value \\
\hline RBC & $5.32 \pm 0.38$ & $5.23 \pm 0.49$ & 0.35 \\
\hline Hemoglobin & $15.12 \pm 1.14$ & $14.8 \pm 1.12$ & 0.37 \\
\hline Hematocrit, vol\% & $44.1 \pm 5.51$ & $44.9 \pm 3$ & 0.46 \\
\hline MCV, fL & $86.6 \pm 6.32$ & $85.75 \pm 4.9$ & 0.36 \\
\hline MCHC, $\mathrm{g} / \mathrm{L}$ & $33.65 \pm 1.0$ & $33.10 \pm 0.71$ & $<0.01$ \\
\hline Platelet count, $10^{9} / \mathrm{L}$ & $249.075 \pm 49$ & $246.525 \pm 49$ & 0.81 \\
\hline ESR & $3.15 \pm 1.61$ & $3.7 \pm 1.18$ & 0.08 \\
\hline RDW & $12.7 \pm 0.61$ & $12.78 \pm 0.6$ & 0.56 \\
\hline WBC, $10^{6} / \mathrm{L}$ & $7.13 \pm 1.5$ & $6.90 \pm 1.29$ & 0.48 \\
\hline Neutrophil & $53.36 \pm 9.14$ & $53.3 \pm 7.74$ & 0.97 \\
\hline Lymphocyte & $43.13 \pm 9.08$ & $42.27 \pm 7.61$ & 0.64 \\
\hline Eosinophil & $2.17 \pm 1.11$ & $2.9 \pm 1.5$ & $<0.001$ \\
\hline Monocyte & $1.57 \pm 1.42$ & $1.45 \pm 0.59$ & 0.61 \\
\hline
\end{tabular}

increased in painting workers exposed to benzene, compared to the control group.
Few studies have demonstrated a relationship between benzene exposure and hematological reactions. Ward re- 
Table 4. Hematological Parameters in Benzene-Exposed and Control Groups, (N, 40)

\begin{tabular}{|c|c|c|c|c|c|c|}
\hline \multirow[t]{2}{*}{ Variables } & \multicolumn{3}{|c|}{ Benzene-Exposed Group } & \multicolumn{3}{|c|}{ Control Group } \\
\hline & Smokers & Nonsmokers & P Value & Smokers & Nonsmokers & P Value \\
\hline RBC & $5.2 \pm 0.59$ & $5.3 \pm 0.53$ & 0.67 & $5.09 \pm 0.55$ & $5.3 \pm 0.39$ & 0.17 \\
\hline Hemoglobin & $14.9 \pm 1.03$ & $15.2 \pm 1.2$ & 0.47 & $15.1 \pm 1.38$ & $14.79 \pm 0.98$ & 0.41 \\
\hline Hematocrit, vol\% & $44.4 \pm 1.9$ & $43.9 \pm 6.8$ & 0.78 & $45.06 \pm 4.02$ & $44.8 \pm 2.45$ & 0.84 \\
\hline MCV, fL & $84.6 \pm 7.4$ & $84.5 \pm 5.6$ & 0.97 & $87.92 \pm 4.62$ & $84.7 \pm 4.76$ & 0.05 \\
\hline MCH,pg & $28.2 \pm 3.07$ & $28.5 \pm 2.2$ & 0.75 & $29.65 \pm 1.23$ & $27.9 \pm 1.84$ & 0.04 \\
\hline MCHC, $\mathrm{g} / \mathrm{L}$ & $33.5 \pm 1.2$ & $33.6 \pm 0.88$ & 0.74 & $33.37 \pm 0.60$ & $32.9 \pm 0.74$ & 0.08 \\
\hline Platelet count, $1^{9} / \mathrm{L}$ & $245.9 \pm 51.6$ & $250.9 \pm 49.5$ & 0.76 & $243.8 \pm 44.5$ & $247.8 \pm 52.8$ & 0.81 \\
\hline ESR & $3.5 \pm 1.7$ & $2.9 \pm 1.4$ & 0.24 & $4.07 \pm 0.95$ & $3.5 \pm 1.2$ & 0.12 \\
\hline RDW & $12.7 \pm 0.59$ & $12.6 \pm 0.64$ & 0.82 & $12.48 \pm 0.48$ & $12.9 \pm 0.61$ & 0.02 \\
\hline$W B C, 10^{6} / L$ & $7.16 \pm 1.64$ & $7.11 \pm 1.57$ & 0.93 & $6.98 \pm 7.74$ & $6.86 \pm 1.49$ & 0.78 \\
\hline Neutrophil & $55.2 \pm 9.2$ & $52.2 \pm 9.09$ & 0.33 & $54.61 \pm 7.43$ & $52.6 \pm 7.95$ & 0.46 \\
\hline Lymphocyte & $40.2 \pm 9.2$ & $44.4 \pm 8.89$ & 0.23 & $40.69 \pm 7.47$ & $43.03 \pm 7.70$ & 0.36 \\
\hline Eosinophil & $2.22 \pm 1.17$ & $2.14 \pm 1.1$ & 0.83 & $3.15 \pm 1.72$ & $2.8 \pm 1.4$ & 0.61 \\
\hline Monocyte & $1.7 \pm 1.54$ & $1.44 \pm 1.35$ & 0.45 & $1.38 \pm 0.65$ & $1.4 \pm 0.57$ & 0.63 \\
\hline
\end{tabular}

Table 5. Multiple Regression Analysis of Each Hematological Parameter and Demographic Information of Painting Workers

\begin{tabular}{|c|c|c|c|c|}
\hline Parameters & Age, $Y$ & Work Experience, $Y$ & Smoking (Yes/No) & BMI \\
\hline RBC & $\mathrm{P}=0.92$ & $\mathrm{P}=0.32$ & $\mathrm{P}=0.54$ & $\mathrm{P}=0.48$ \\
\hline Hemoglobin & $\mathrm{P}=0.67$ & $\mathrm{P}=0.1$ & $\mathrm{P}=0.58$ & $\mathrm{P}=0.49$ \\
\hline Hematocrit, vol\% & $\mathrm{P}=0.37$ & $\mathrm{P}=0.72$ & $P=0.39$ & $\mathrm{P}=0.81$ \\
\hline MCV, fL & $P=0.99$ & $\mathrm{P}=0.92$ & $P=0.81$ & $P=0.43$ \\
\hline MCHC, $\mathrm{g} / \mathrm{L}$ & $\mathrm{P}=0.50$ & $P=0.09$ & $\mathrm{P}=0.98$ & $\mathrm{P}=0.53$ \\
\hline Platelet count, $1^{9} / \mathrm{L}$ & $\mathrm{P}=0.59$ & $P=0.96$ & $\mathrm{P}=0.7$ & $\mathrm{P}=0.90$ \\
\hline ESR & $P=0.68$ & $\mathrm{P}=0.61$ & $P=0.65$ & $P=0.08$ \\
\hline RDW & $\mathrm{P}=0.87$ & $\mathrm{P}=0.89$ & $\mathrm{P}=0.99$ & $\mathrm{P}=0.52$ \\
\hline $\mathrm{WBC}, \mathbf{1 0}^{6} / \mathrm{L}$ & $P=0.45$ & $P=0.88$ & $\mathrm{P}=0.82$ & $P=0.55$ \\
\hline Neutrophil & $P=0.15$ & $P=0.13$ & $\mathrm{P}=0.48$ & $P=0.15$ \\
\hline Lymphocyte & $\mathrm{P}=0.23$ & $\mathrm{P}=0.27$ & $\mathrm{P}=0.43$ & $P=0.12$ \\
\hline Eosinophil & $\mathrm{P}=0.4$ & $\mathrm{P}=0.12$ & $\mathrm{P}=0.54$ & $\mathrm{P}=0.38$ \\
\hline Monocyte & $\mathrm{P}=0.12$ & $P=0.02$ & $P=0.5$ & $\mathrm{P}=0.57$ \\
\hline
\end{tabular}

ported that at benzene concentrations below $10 \mathrm{ppm}$, reduction in CBC count was unlikely to occur. They demonstrated a correlation between exposed workers and reduction in WBC and RBC (33). Khuder demonstrated that exposure to low benzene concentrations (range, 0.14-2.08 ppm) resulted in reduced $\mathrm{RBC}$ and platelet count in pollutantexposed workers, who were followed-up longitudinally
(30).

Exposure to high concentrations of benzene $(>100$ ppm) can lead to higher levels of MCV and neutrophil count, despite lower MCHC levels (22). According to the finding of this study, no significant differences were observed in the lymphocyte count of benzene-exposed and control groups. Moreover, Bogadi reported no significant 
differences in lymphocyte count and different levels of exposure to benzene (21).

In addition, in this study, no significant differences were observed in the platelet count of painting workers, compared to the control group. Muzaffer reported that platelet count was always normal in workers with exposure to benzene (34). According to the finding of this study, there was no significant difference in the hematocrit, hemoglobin, MCV, and MCH levels of painting workers, compared to the control group.

Many authors have shown that routine blood tests are not sensitive enough to detect early changes due to the toxic effects of benzene $(17,28,31,35-38)$. According to the finding of this study, exposure to benzene concentrations below1 ppm was reported in painters, causing few changes in blood cells, besides hematological changes associated with exposure to higher concentrations of benzene.

According to the finding of this study, eosinophil is more sensitive than lymphocyte or neutrophil. In addition, the mean monocyte, lymphocyte, and neutrophil levels increased in painting workers exposed to benzene, compared to the control group. However, the statistical analysis showed no significant differences between painting workers and controls. Overall, benzene is a hematotoxic compound, causing a reduction in the total WBC, granulocyte, and lymphocyte counts in workers with various levels of exposure to benzene (39).

Few studies have shown an association between risk of leukemia and exposure to lower concentrations of benzene in the workplace (40). Yin reported that total WBC reduced similarly in workers exposed to benzene (41). Therefore, in some countries, even lower levels have been adopted (0.5 ppm in Sweden) (42). Overall, education about the health hazards and toxicity of benzene in developing countries, including Iran, is essential.

In conclusion, this study showed that painting workers with benzene exposure are at a higher risk of health hazards, such as leukemia, lymphoma, and hematological changes. Concentration of pollutants in the workplace should be measured so that sampling and analysis of VOCs can provide valuable information on preventive and control measures.

\section{Acknowledgments}

The authors would like to thank the Department of Health, Safety, and Environment of Automobile Manufacturing for supporting this study.

\section{References}

1. Golbabaei F, Karimi A, Neghab M, Pourmand MR, Bakhtiari R, Mohammad K. Design, construction and optimization of two phase stirred tank bioreactor for elimination of xylene from airstream [In Persian]. J Health SafWork. 2013;3(2):59-66.

2. Golbabaie F, Eskandari D, Rezazade Azari M, Jahangiri M, Rahimi M, Shahtaheri J. Health risk assessment of chemical pollutants in a petrochemical complex [In Persian]. Iran Occup Health. 2012;9(3):11-21.

3. Eisaei HR, Dehrashid A, Shaho S, Khani MR, Hashemi SM. Assessment and control of VOCs emitted from gas stations in Tehran, Iran. Pollution. 2015;1(4):363-71.

4. Smith MT. Advances in understanding benzene health effects and susceptibility. Annu Rev Public Health. 2010;31:133-48 2 p following 148. doi: 10.1146/annurev.publhealth.012809.103646. [PubMed: 20070208].

5. Rappaport SM, Kim S, Lan Q, Li G, Vermeulen R, Waidyanatha S, et al. Human benzene metabolism following occupational and environmental exposures. Chem Biol Interact. 2010;184(1-2):189-95. doi: 10.1016/j.cbi.2009.12.017. [PubMed: 20026321].

6. Wallace L. Environmental exposure to benzene: an update. Environ Health Perspect. 1996;104 Suppl 6:1129-36. doi: 10.2307/3433152. [PubMed: 9118882].

7. Fustinoni S, Consonni D, Campo L, Buratti M, Colombi A, Pesatori $\mathrm{AC}$, et al. Monitoring low benzene exposure: comparative evaluation of urinary biomarkers, influence of cigarette smoking, and genetic polymorphisms. Cancer Epidemiol Biomarkers Prev. 2005;14(9):223744. doi: 10.1158/1055-9965.EPI-04-0798. [PubMed: 16172237].

8. Hinwood AL, Rodriguez C, Runnion T, Farrar D, Murray F, Horton A, et al. Risk factors for increased BTEX exposure in four Australian cities. Chemosphere. 2007;66(3):533-41. doi: 10.1016/j.chemosphere.2006.05.040. [PubMed:16837022].

9. Weisel CP. Benzene exposure: an overview of monitoring methods and their findings. Chem Biol Interact. 2010;184(1-2):58-66. doi: 10.1016/j.cbi.2009.12.030. [PubMed: 20056112].

10. Glass DC, Gray CN, Jolley DJ, Gibbons C, Sim MR, Fritschi L, et al. Leukemia risk associated with low-level benzene exposure. Epidemiology. 2003;14(5):569-77. doi: 10.1097/01.ede.0000082001.05563.e0. [PubMed: 14501272].

11. Zhang L, Eastmond DA, Smith MT. The nature of chromosomal aberrations detected in humans exposed to benzene. Crit Rev Toxicol. 2002;32(1):1-42. doi:10.1080/20024091064165. [PubMed: 11846214].

12. Selling L. Benzol as a Leucotoxin: Studies on the Degeneration and Regeneration of the Blood and Haemopoietic Organs. US: Johns Hopkins Press; 1913.

13. Weiskotten HG, Gibbs CB, Boggs EO, Templeton ER. The Action of Benzol : VI. Benzol Vapor Leucopenia (Rabbit). J Med Res. 1920;41(4):42538. [PubMed: 19972514].

14. Weiskotten HG, Schwartz SC, Steensland HS. The Action of Benzol : II. The Deuterophase of the Diphasic Leucopenia and Antigen-Antibody Reaction. J Med Res. 1916;35(1):63-9. [PubMed: 19972322].

15. Hayes RB, Songnian Y, Dosemeci M, Linet M. Benzene and lymphohematopoietic malignancies in humans. Am J Ind Med. 2001;40(2):11726. [PubMed: 11494338].

16. Snyder R. Leukemia and benzene. Int J Environ Res Public Health 2012;9(8):2875-93. doi: 10.3390/ijerph9082875. [PubMed: 23066403].

17. Fishbeck WA, Townsend JC, Swank MG. Effects of chronic occupational exposure to measured concentrations of benzene. J Occup Med. 1978;20(8):539-42. doi: 10.1097/00043764-197808000-00005. [PubMed: 690738].

18. Liu CS, Tsai JH, Kuo SW. Comparisons of complete blood counts and urinary benzene metabolites after exposure to benzene. Mid-Taiwan J Med. 2000;5(4):235-42.

19. Wang X, Liu N, Guan W, Pang S, Bai Y. P. , Xu GH, et al. Effect of shortterm benzene exposure on peripheral blood and chromosomal damage among workers. Int J Occup Environ Med. 2010;27(8):464-7. 
20. Yardley-Jones A, Anderson D, Jenkinson PC, Lovell DP, Blowers SD, Davies MJ. Genotoxic effects in peripheral blood and urine of workers exposed to low level benzene. Br J Ind Med. 1988;45(10):694-700. doi: 10.1136/oem.45.10.694. [PubMed: 3196663].

21. Bogadi-Sare A, Zavalic M, Trosic I, Turk R, Kontosic I, Jelcic I. Study of some immunological parameters in workers occupationally exposed to benzene. Int Arch Occup Environ Health. 2000;73(6):397-400. [PubMed: 11007343].

22. Bogadi-Sare A, Zavalic M, Turk R. Utility of a routine medical surveillance program with benzene exposed workers. Am J Ind Med. 2003;44(5):467-73. doi:10.1002/ajim.10296. [PubMed:14571510].

23. Rothman N, Li GL, Dosemeci M, Bechtold WE, Marti GE, Wang YZ, et al. Hematotoxicity among Chinese workers heavily exposed to benzene. Am J Ind Med. 1996;29(3):236-46. doi: 10.1002/(SICI)10970274(199603)29:3<236::AID-AJIM3>3.0.CO;2-O. [PubMed: 8833776].

24. Aksoy M, Dincol K, Akgun T, Erdem S, Dincol G. Haematological effects of chronic benzene poisoning in 217 workers. Br J Ind Med. 1971;28(3):296-302. doi: 10.1136/oem.28.3.296. [PubMed: 5557851].

25. Goldstein BD. Biological and ambient monitoring of benzene in the workplace. J Occup Med. 1986;28(10):1051-4. doi: 10.1097/00043764198610000-00028. [PubMed:3464702].

26. Lan Q, Zhang L, Li G, Vermeulen R, Weinberg RS, Dosemeci M, et al. Hematotoxicity in workers exposed to low levels of benzene. Science. 2004;306(5702):1774-6. doi: 10.1126/science.1102443. [PubMed: 15576619].

27. Hernberg S, Savilahli M, Ahlman K, Asp S. Prognostic Aspects of Benzene Poisoning. J Occup Environ Med. 1967;9(2):86. doi: 10.1097/00043764-196702000-00037.

28. Collins JJ, Conner P, Friedlander BR, Easterday PA, Nair RS, Braun J. A study of the hematologic effects of chronic low-level exposure to benzene. J Occup Med. 1991;33(5):619-26. [PubMed: 1870014].

29. Guenel P, Imbernon E, Chevalier A, Crinquand-Calastreng A, Goldberg M. Leukemia in relation to occupational exposures to benzene and other agents: a case-control study nested in a cohort of gas and electric utility workers. Am J Ind Med. 2002;42(2):87-97. doi: 10.1002/ajim.10090. [PubMed: 12125084]

30. Khuder SA, Youngdale MC, Bisesi MS, Schaub EA. Assessment of complete blood count variations among workers exposed to low levels of benzene.JOccup Environ Med. 1999;41(9):821-6. doi:10.1097/00043764199909000-00015. [PubMed: 10491799].

31. Kipen HM, Cody RP, Goldstein BD. Use of longitudinal analysis of peripheral blood counts to validate historical reconstructions of benzene exposure. Environ Health Perspect. 1989;82:199-206. doi: 10.1289/ehp.8982199. [PubMed: 2792041].

32. Snyder R, Kalf GF. A perspective on benzene leukemogenesis. Crit
Rev Toxicol. 1994;24(3):177-209. doi: 10.3109/10408449409021605. [PubMed: 7945890]

33. Ward E, Hornung R, Morris J, Rinsky R, Wild D, Halperin W, et al. Risk of low red or white blood cell count related to estimated benzene exposure in a rubberworker cohort (1940-1975). Am J Ind Med. 1996;29(3):247-57. doi: 10.1002/(SICI)1097-0274(199603)29:3<247::AIDAJIM4>3.0.CO;2-N. [PubMed: 8833777].

34. Aksoy M, Dincol K, Erdem S, Akgun T, Dincol G. Details of blood changes in 32 patients with pancytopenia associated with longterm exposure to benzene. $B r$ J Ind Med. 1972;29(1):56-64. doi: 10.1136/oem.29.1.56. [PubMed: 5060246].

35. Collins JJ, Ireland BK, Easterday PA, Nair RS, Braun J. Evaluation of lymphopenia among workers with low-level benzene exposure and the utility of routine data collection. J Occup Environ Med. 1997;39(3):2327. [PubMed: 9093975].

36. Cowles SR, Bennett JM, Ross CE. Medical surveillance for leukemia at a petrochemical manufacturing complex: four-year summary. J Occup Med. 1991;33(7):808-12. doi: 10.1097/00043764-199107000-00015. [PubMed: 1890492].

37. Swaen GM, van Amelsvoort L, Twisk JJ, Verstraeten E, Slootweg R, Collins JJ, et al. Low level occupational benzene exposure and hematological parameters. Chem Biol Interact. 2010;184(1-2):94-100. doi: 10.1016/j.cbi.2010.01.007. [PubMed: 20074561].

38. Tsai SP, Wen CP, Weiss NS, Wong O, McClellan WA, Gibson RL. Retrospective mortality and medical surveillance studies of workers in benzene areas of refineries. J Occup Med. 1983;25(9):685-92. doi: 10.1097/00043764-198309000-00018. [PubMed: 6631569].

39. McHale CM, Zhang L, Lan Q, Li G, Hubbard AE, Forrest MS, et al. Changes in the peripheral blood transcriptome associated with occupational benzene exposure identified by cross-comparison on two microarray platforms. Genomics. 2009;93(4):343-9. doi: 10.1016/j.ygeno.2008.12.006. [PubMed: 19162166].

40. Schnatter AR, Rosamilia K, Wojcik NC. Review of the literature on benzene exposure and leukemia subtypes. Chem Biol Interact. 2005;153154:9-21. doi: 10.1016/j.cbi.2005.03.039. [PubMed: 15935796].

41. Yin SN, Hayes RB, Linet MS, Li GL, Dosemeci M, Travis LB, et al. A cohort study of cancer among benzene-exposed workers in China: overall results. Am J Ind Med. 1996;29(3):227-35. doi: 10.1002/(SICI)10970274(199603)29:3<227::AID-AJIM2>3.0.CO;2-N. [PubMed: 8833775].

42. Ray MR, Roychoudhury S, Mukherjee S, Lahiri T. Occupational benzene exposure from vehicular sources in India and its effect on hematology, lymphocyte subsets and platelet P-selectin expression. Toxicol Ind Health. 2007;23(3):167-75. doi: 10.1177/0748233707080907. [PubMed: 18220159]. 